\title{
ArcheoSciences
}

Revue d'archéométrie

33 (suppl.) | 2009

Mémoire du sol, espace des hommes

\section{Magnetometry and soil magnetism on Celtic square enclosures in Bavaria, Southern Germany}

\author{
Karin Berghausen and Jörg W. E. Fassbinder
}

\section{(2) OpenEdition}

1 Journals

\section{Electronic version}

URL: https://journals.openedition.org/archeosciences/1221

DOI: 10.4000/archeosciences. 1221

ISBN: 978-2-7535-1599-4

ISSN: 2104-3728

Publisher

Presses universitaires de Rennes

\section{Printed version}

Date of publication: 30 October 2009

Number of pages: $27-29$

ISBN: 978-2-7535-0943-6

ISSN: 1960-1360

\section{Electronic reference}

Karin Berghausen and Jörg W. E. Fassbinder, "Magnetometry and soil magnetism on Celtic square enclosures in Bavaria, Southern Germany", ArcheoSciences [Online], 33 (suppl.) | 2009, Online since 30 October 2011, connection on 21 September 2021. URL: http://journals.openedition.org/ archeosciences/1221; DOI: https://doi.org/10.4000/archeosciences.1221 


\title{
Magnetometry and soil magnetism on Celtic square enclosures in Bavaria, Southern Germany
}

\author{
Karin Berghausen* and Jörg Fassbinder*
}

Key words: Square enclosures, Magnetometer prospection, Soil magnetism, Susceptibility, Excavation.

\section{INTRODUCTION}

A widely spread Celtic archaeological feature in southern Germany, ranging from eastern France to the western Czech Republic, are the so called "Viereckschanzen" or "Square Enclosures", dating to the La Tène period 200 to 50 B.C. They consist of nearly square systems of earth walls with only one entrance gap and uninterrupted surrounding ditches. Inside these enclosures traces of buildings are known.

Since 1993 more than 20 magnetometer surveys have been carried out. In order to explain the sometimes ambiguous prospection results, soil magnetism research complements magnetometry.

\section{ArChaeological BaCKGround}

Four earth walls, about 4 meters high and 8 meters wide, formed a trapezoid or an imperfect square, mostly in the size range from $70 \mathrm{~m} \times 70 \mathrm{~m}$ to $100 \mathrm{~m} \times 100 \mathrm{~m}$, in a few cases even up to $400 \mathrm{~m}$ x $400 \mathrm{~m}$ (Schwarz, 1959). An uninterrupted ditch, in general 3 meters deep and 6 meters wide, surrounded the walls tightly, supplying the material for the walls. One single entrance gap was left in the wall, almost in the middle of one side, mostly to the east, sometimes in the south or west, but never on the north side. A wooden bridge served to cross the ditch on the entrance side.
23 magnetometer surveys and nearly 50 excavations in such square enclosures as well as aerial prospection maps documented construction details of their inner area. We know about the existence of wooden door buildings, normally one main building opposite the entrance and some smaller houses close to the walls; wells are possible. Assuming a usage of 150 years the occurrence of 4-6 wooden house constructions in each enclosure does not indicate an intensive settlement activity. Probably square enclosures formed the centre of a small agricultural settlement, but ritual use is also possible.

Remnants of the walls and ditches can be found mainly in forested areas, although the majority of them are completely destroyed. Compared to 165 enclosures in Bavaria still visible above ground, 111 enclosures are totally levelled and were only visible from the air and discovered by aerial prospecting.

\section{Magnetic PRospecting}

When prospecting Celtic Square Enclosures in Bavaria with the Smartmag caesium magnetometer, we get quite different results depending on the soil situation. In the eastern Bavarian loess soils and parabrown earth we observe very sharp and clear positive magnetic anomalies for the ditch, wells and post holes of former buildings. An example is the prospection result of Manndorf (Berghausen, 2007). On the

* Bavarian State Department of Monuments and Sites, Hofgraben 4, 80539 Munchen, Germany. (karin.berghausen@blfd.bayern.de), (joerg.fassbinder@ blfd.bayern.de) 
other hand, there are very poor results on wet loamy soils and gleys with almost no result at all, although in the aerial photo there seems to be a similar state of preservation (or destruction) for all of these square enclosures. This is known to result from changing magnetite and maghemite to less magnetic minerals like goethite and lepidocrocite due to backwater effects. The prospection of the square enclosure of Fehmbach near Deggendorf in the Danube area however resulted in a mixture of positive and negative magnetic anomalies in the ditch.

The enclosure of Fehmbach is situated on several meters of glacial gravel overlaid by about $70 \mathrm{~cm}$ of alluvial clay deposits from the river Danube nearby, and topsoil. The western part of the square enclosure had already been excavated in 2000, the eastern part lay fallow. We prospected this area in April 2008 and the ground was still undisturbed, see figure1. During the excavation of the eastern part in November 2008, we had the opportunity to take soil samples and undertake some in situ measurements of magnetic susceptibility in a $20 \times 20 \mathrm{~cm}$ grid in the ditch profiles, using the SM30 Kappa meter by ZH instruments. The ditch fillings consisted of a mixture of the gravel-rich quartzitic former wall material and loamy topsoil. Additionally, we repeated our magnetometer surveys after removing the topsoil and clays directly above the gravel layer.

\section{SOIL MAGNETIC MEASUREMENTS}

In the in situ and laboratory susceptibility measurements we could clearly distinguish between the two mayor components of the ditch fillings. We found topsoil susceptibilities of nearly $0.2 \times 10^{-3} \mathrm{SI}$ units, compared to about $0.1 \times 10^{-3}$ SI units in the gravel-rich areas. Laboratory measurements on some bigger single pieces of quartzite resulted in negative susceptibility values.

This helps to explain the results of the magnetometer survey, undertaken before the excavation. The southern part of the ditch, measured over the later profile C-D, shows negative anomalies towards the inner part of the square enclosure (wall side) and a positive trend towards the outer area, see figure 1 . The dark green line shows the ditch according to the excavation after removing about $70 \mathrm{~cm}$ of topsoil, light green is the supposed ditch width over undisturbed ground. Some archaeological features (blue) had already been verified by the excavation (light blue), which is to be continued in spring 2009. Outlined in red are magnetic dipoles in the upper soil.

In the corresponding photo of profile C-D, figure 2, we clearly see a big package of low susceptibility gravel coming

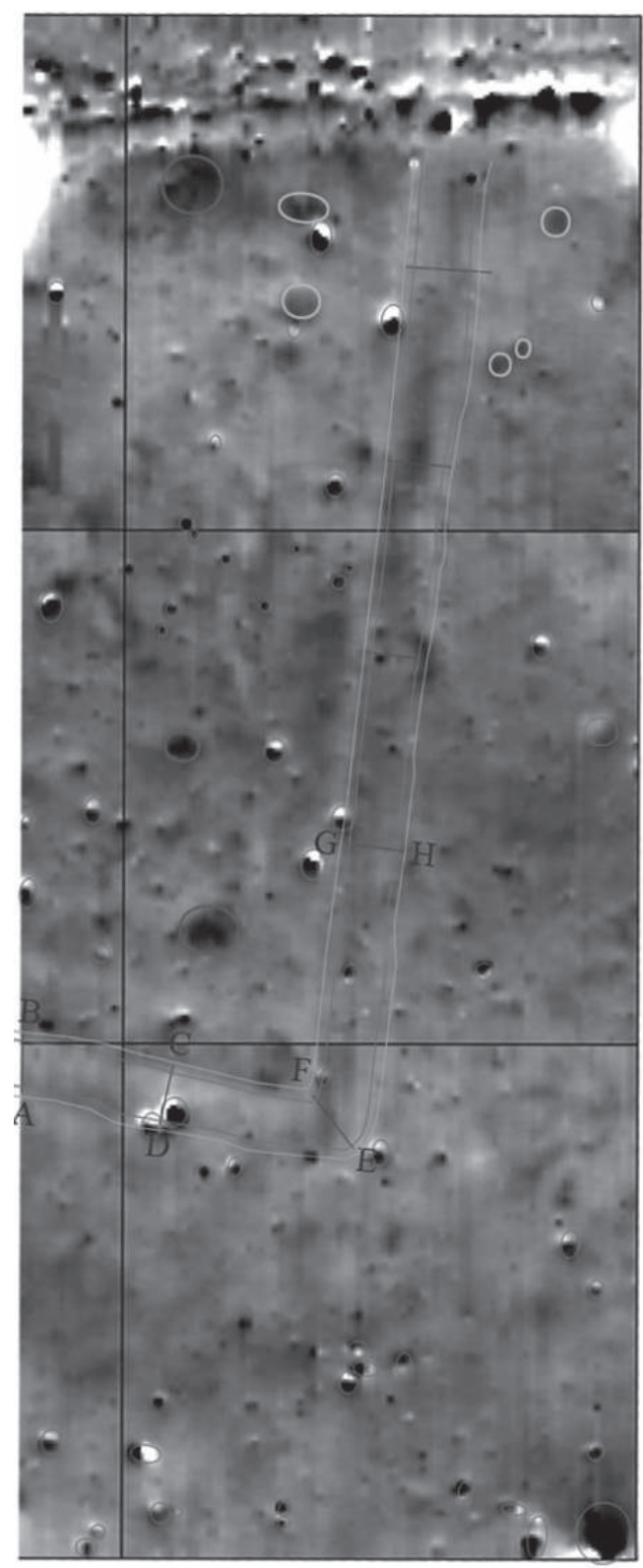

Figure 1 (see color plate): Magnetogram of the eastern part of the square enclosure of Fehmbach. Section C-D is shown in figures 2 and 3. Smartmag SM4G-Special, dynamics +/- $5 \mathrm{nT}$, grid size $40 \mathrm{x}$ $40 \mathrm{~m}$, sampling density $50 \times 10 \mathrm{~cm}$, interpolated to $25 \mathrm{x} 25 \mathrm{~cm}$.

from the wall side (to the left), whereas from the outer side the ditch was filled with loamy topsoil with higher susceptibility values, see also figure 3 . In the eastern ditch the positive anomalies in the magnetogram also correspond to a higher degree of loamy soil. 
Figure 2 (upper): Photo of section C-D in fig. 1, with the susceptibility measurement grid of $20 \times 20$ $\mathrm{cm}$. The wall side of the square enclosure is to the left.

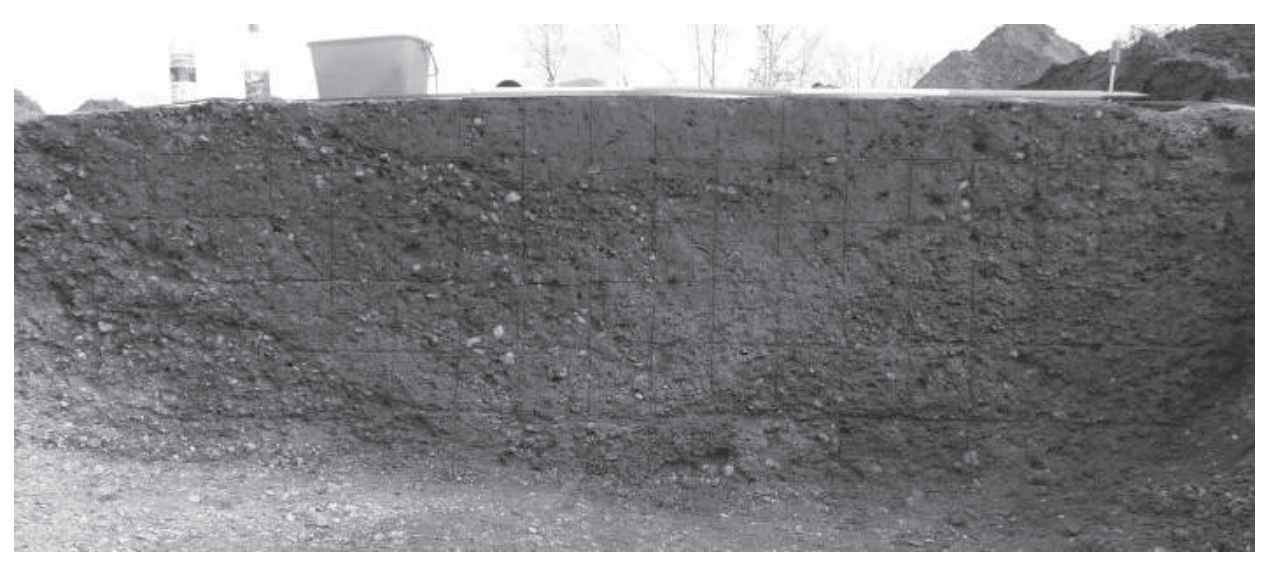

Figure 3 (lower): Results of susceptibility measurements in the profile section C-D shown in figure 2 . SM30 Kappa meter by ZH instruments, 20 x $20 \mathrm{~cm}$ grid, interpolated to $4 \mathrm{x} 4 \mathrm{~cm}$ by Golden Software Surfer.

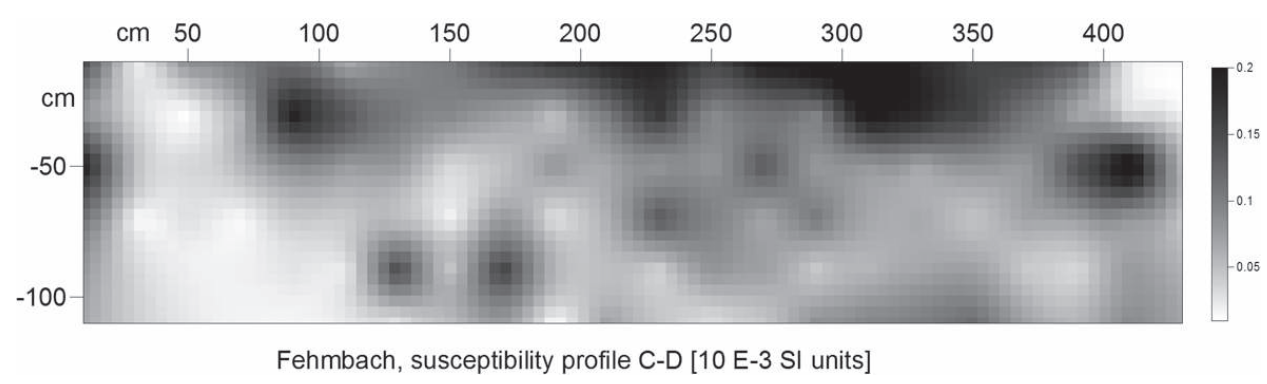

\section{Conclusion}

The example of Fehmbach shows that even within one single archaeological feature like the ditch of a square enclosure one cannot expect a uniform type of magnetic anomaly. In any case, for a better understanding of prospection results the soil type and local filling materials have to be taken into account.

\section{References}

Berghausen, K., 2007. Magnetometerprospektion an der spätkeltischen Viereckschanze von Manndorf. Das Arch. Jahr in Bayern 2007, 56 ff.

SCHWARz, K., 1959. Atlas der spätkeltischen Viereckschanzen, München. 